\title{
Exclusionary Practices and the Antitrust Laws*
}

\author{
Richard A. Posnert
}

Much public and private enforcement of the antitrust laws is based on a concern with exclusion, or in antitrust jargon "foreclosure," of competing firms from the market. Such seemingly disparate practices as tying arrangements, predatory pricing, vertical mergers, exclusive dealing, and group boycotts are all challenged as tending to exclude competitors on grounds unrelated to the superior efficiency of the firm or firms doing the excluding.

The economists of the "Chicago School" of antitrust analysis, Aaron Director and others, ${ }^{1}$ have mounted a powerful attack on the implicit economic theory that underlies the current policy of the law towards the allegedly exclusionary practices. One purpose of this article is to restate these criticisms and in a few places extend them. The article will also indicate some respects in which I consider the criticisms overstated. Another purpose is to indicate the precise implications for antitrust policy of an appropriately qualified critique of the economic premises of current policy. These implications concern both the substantive content of the law and the allocation of responsibilities for law enforcement.

\section{A Typology of Antitrust Violations}

To organize the subsequent analysis, it is helpful to indicate the three different kinds of practices with which antitrust law arguably should be concerned.

The first category ("collusive practices") consists of practices by which competing firms voluntarily eliminate competition among themselves so as to become able to restrict output and raise prices. The major examples are cartelization and mergers to monopoly. The latter is nicely illustrated by the formation of the United States Steel Corporation.2

* Aaron Director, Gary S. Becker, Ward S. Bowman, Jr., Kenneth W. Dam, William M. Landes, Melvin W. Reder, George J. Stigler, Donald F. Turner, Oliver E. Williamson, and participants in the Industrial Organization Workshop of the University of Chicago commented helpfully on earlier drafts of this paper.

+ Professor of Law, University of Chicago.

1 The most recent-and a very worthwhile-product of the Chicago School is W. Bowman, Jr., Patent and Antitrust Law: a Legal and Economic Appraisal (1973).

2 See United States v. United States Steel Corp., 251 U.S. 417 (1920); Stigler, The Domi- 
U.S. Steel apparently had such a large fraction of the productive capacity of the steel industry that it could obtain monopoly profits by limiting its output. If the remaining firms in the industry had been able to expand their output rapidly without incurring higher production costs, or if new firms could have entered the industry rapidly and operated at a cost level no higher than that of the existing firms, U.S. Steel's limitation of its output would not have resulted in any significant reduction of the industry's output; the market price would therefore have remained at the competitive level. Even if these conditions were not fulfilled, as long as U.S. Steel took no steps to prevent its competitors from gradually increasing their output or new firms from gradually entering the industry, it could not expect its monopoly position to persist indefinitely. The company did make some efforts to collude with competitors, but it made no attempt to exclude them; as a result, its market share declined steadily (from about 60 percent when the company was formed in 1901 to about 20 percent today). The history of U.S. Steel indicates the policy and the eventual position of the monopolist firm that does not engage in exclusionary practices.

Next, there are the practices ("exclusionary practices") by which firms attempt to exclude a rival, other than by having lower costs and therefore lower prices. Predatory pricing, tying arrangements, vertical integration, exclusive dealing, and group boycotts are the main examples of the practices that belong-or are thought to belong-in this category.

Finally, there are practices by which firms that have a monopoly, here defined simply as freedom from the competition of close substitutes, seek to maximize their profits other than by colluding with or excluding potential competitors. Price discrimination is the major, but not the only, practice in this category. For want of a better term, we may call the practices in this category "unilateral noncoercive monopolizing."

Can a practice that cannot be put into any of these categories rationally be considered a violation of the antitrust laws? If the purpose of those laws is to promote competition in order to increase economic efficiency, the answer is, I believe, "no." As to whether the antitrust laws have other purposes, it is relevant to point out that no one has ever articulated a coherent, objective, and operational noneconomic theory of antitrust law. The following analysis assumes that the only purpose of antitrust law is to promote efficiency.

nant Firm and the Inverted Umbrella, 8 J. LAW \& ECoN. 167 (1965), reprinted in G. STrGLER, The ORGanization OF INDUSTRY, 108 (1968). 
The focus of this article is on the second category, exclusionary practices. However, because practices that should be considered unilateral noncoercive monopolizing are frequently classified in the second category, and because the policy of the law towards collusive practices is sometimes inconsistent with its policy towards exclusionary practices, the typology is worth introducing. In addition, it is an improvement over the conventional division of antitrust practices into "horizontal" and "vertical," which is not a useful division. Practices may be horizontal, yet not offend any rational antitrust policy; the territorial restrictions challenged in United States $v$. Sealy, Inc. ${ }^{3}$ were, as the Supreme Court found, horizontal rather than vertical, but neither their purpose nor their likely effect was to curtail output and raise prices. Vertical restraints may fall into either the second or the third category, and can have very different properties. Some vertical restraints even fall into the first category. ${ }^{4}$ And a horizontal practice, such as a boycott organized by a group of competing firms, may operate like a conventional vertical restraint, such as exclusive dealing, rather than like a cartel agreement.

\section{Tying Arrangements and Other Unilateral Noncoercive Methods of Maximizing Monopoly Profits}

One of the achievements of the Chicago School has been to show that some practices thought to be exclusionary practices, notably tying, really should be considered as monopoly profit maximization other than by collusion or exclusion-unilateral noncoercive monopolizing. Peo- ple used to regard tying as a method by which a firm having a monopoly in one market (for example computers) could obtain a monopoly of a second product (such as computer punch cards) by requiring all purchasers of the first product also to buy the second from it. We now know that this "leverage" theory is incorrect. If the price of the second product is higher than the purchaser would have to pay on the open market, he will treat the difference as an increase in the price of the first product and his demand for the product will decline. In the absence of price discrimination, it can be shown that the computer monopolist will gain nothing from the second monopoly. Tying does, however, enable the monopolist to practice price discrimination. By providing the computer

3388 U.S. 350 (1967). A group of small mattress manufacturers adopted the Sealy trademark. They agreed that on sales of mattresses under the Sealy name each member would be limited to a designated territory. The reason for this "division of markets" was to encourage each member to promote the trademark vigorously. Without the division, a member might have exploited the goodwill created by another member's promotional activities to undersell the latter. This arrangement would result in a general reluctance to promote the mark.

4 Some resale price maintenance schemes are of this type. 
at cost and selling each card at a monopoly price, the computer monopolist can vary the charge for computing according to the amount, and thus presumably the value, of each purchaser's use. ${ }^{5}$

This analysis of tying, although never refuted, ${ }^{\circ}$ has had no impact on policy. There are, I conjecture, three reasons for this disregard. ${ }^{7}$ First, some commentators argued that to show the purpose of tying to be discrimination rather than exclusion missed the point-the effect was exclusionary and that was all that mattered. ${ }^{8}$ But there need not be an exclusionary effect. The computer monopolist in our example has no reason to displace the existing producers of punch cards and produce cards himself, provided the existing producers are competitive with one another and efficient; he only wants the sales of cards channeled through him so that he can reprice them. There will be an exclusionary effect if the purpose of the tie-in is to protect the manufacturer's goodwill rather than to discriminate. ${ }^{9}$ Exclusion in that instance, however, results solely from the superior efficiency of the tied sale to a sale of the products separately, and the tie-in should be permitted. The Supreme Court brushed aside the goodwill argument, emphasizing that the manufacturer had an alternative that would have restricted competition less: he could have issued specifications that any manufacturer of punch cards would be required to meet. The central issue, however, is the cost, rather than the existence, of an alternative. If the purpose of imposing the tie-in really was to protect goodwill rather than to discriminate, the specifications alternative was probably less efficient than the tie-in; otherwise, the manufacturer would have promulgated specifications voluntarily. ${ }^{10}$ In these circumstances, to hold that the tie-in un-

5 Professor Ronald H. Coase questions this analysis. He doubts that differences in quantity demanded accurately indicate differences in elasticity of demand and suggests that tie-ins may have a different explanation, one connected with the difficulty of monopolizing a durable good. See text at note 22 infra. True, a purchaser in large quantity has a greater incentive to search for substitute products than the small-quantity purchaser; his demand might therefore be more elastic than the small purchaser's. But the quantity of his purchases could also mean that he had failed to find good substitutes, indicating that his demand was less elastic. It is obviously difficult to decide a priori whether Professor Coase's point is correct.

6 But see note 5 supra.

7 A fourth possible reason is that the theory was never subjected to an empirical test, but competing theories have never been tested empirically either.

8 C. KAysen \& D. TURner, ANTITRUST Policy: AN Economic AND Legal ANAysis 157 (1959); Turner, The Validity of Tying Arrangements Under the Antitrust Laws, 72 Harv. L. REv. 50, 63 n.42 (1958).

- Indeed, this argument was made in the punch card case. International Business Mach. Corp. v. United States, 298 U.S. 131 (1936).

10 It is possible, but unlikely, that the alternatives are equally efficient. Another possibility is that the computer manufacturer makes, rather than buys, the cards in order to have a colorable goodwill argument. 
lawfully restricts competition is tantamount to saying that any time a monopoly producer decides to handle a step in the production process internally, instead of inviting competitive bids, he is guilty of monopolizing, because he is unnecessarily restricting competition.

Second, it has been argued that tying makès new competition lesss likely, because a firm wanting to enter the market for the tying product must enter the market for the tied product as well-a new computer manufacturer would have to produce his own cards. ${ }^{11}$ This argument is incorrect, however, if the existing computer manufacturer is buying and repricing, rather than making, cards. If he is manufacturing cards, then there is a presumption that the tie-in has an efficiency justification. Moreover, in almost every tying case the tied product has been a trivial adjunct to the tying product; a firm would have no difficulty in procuring the requisite cards or ink ${ }^{12}$ or salt ${ }^{13}$ to supply together with his computer, duplicating equipment, or salt machinery.

Third, to identify a practice as a form of price discrimination is not to commend it in most people's eyes. I part company with some of my colleagues at the University of Chicago by asserting that there is a substantial economic basis for the hostility to price discrimination. This basis is best explained with the aid of the two simple diagrams in Figure 1.

The left-hand diagram depicts a monopolist who is charging a single price rather than discriminating. In conventional economic analysis the economic cost of this monopoly would be limited to the triangle labeled "deadweight loss." This area is the lost value to consumers that the monopolist is unable to capture by his higher price. The larger area labeled "monopoly profits" is not regarded as a cost since that loss to consumers is exactly offset by the added revenues to the seller; there is merely a transfer of wealth. But this way of analyzing the problem is incomplete. It ignores the fact that firms will incur costs in competing to become monopolists until the expected returns to monopoly are zero. The expenditures on this competitive activity are social costs of monopoly in addition to the deadweight loss. ${ }^{14}$

11 See, e.g., C. KAYSEN \& D. TURNER, supra note 8.

12 Henry v. A.B. Dick Co., 224 U.S. 1 (1912).

13 International Salt Co. v. United States, 332 U.S. 392 (1947).

14 I am not, of course, speaking of expenditures simply on increasing output. Such expenditures would result in a reduction in the monopoly price, eventually to the competitive level, and in the consequent elimination of monopoly profits. I am speaking rather of expenditures on securing a monopoly position, for example, expenditures incidental to the formation of a cartel. Sometimes expenditures for the purpose of securing a monopoly have 

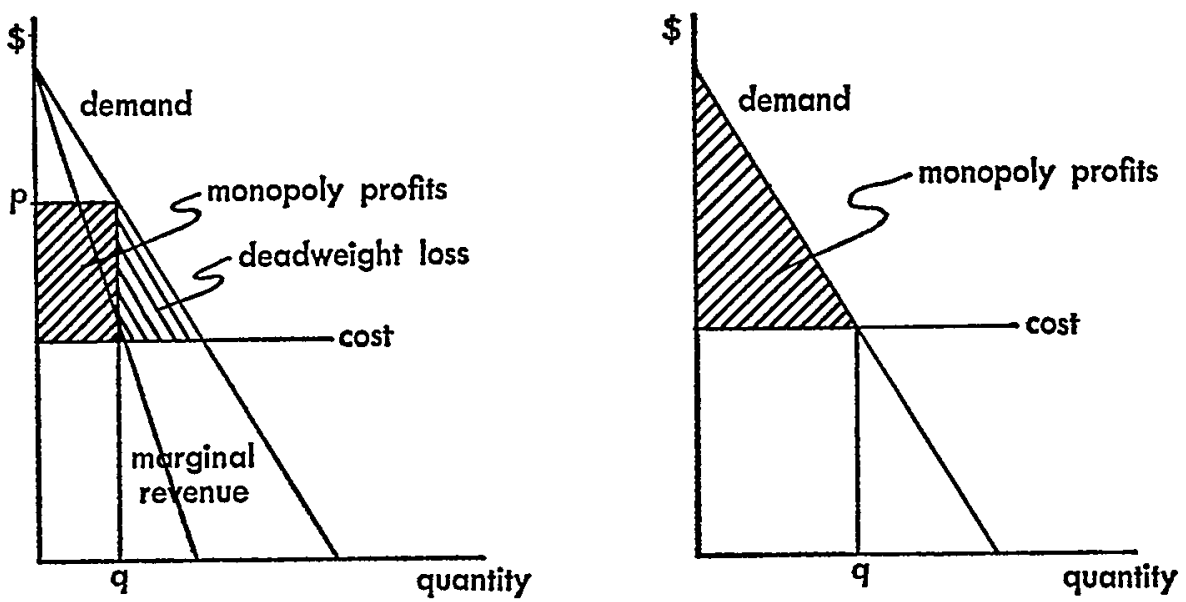

FIGURE 1

An analogy can be drawn to theft. ${ }^{15}$ At a superficial level of analysis, a theft unaccompanied by injury or other damage represents a pure transfer payment and is therefore not a source of social cost. Theft does impose social costs, however, in thieves' time and tools, in victim self-protection, and the like. The higher the returns to theft, the greater will be the resources invested in thieving (and protecting against theft), until cost and gain at the margin are equated. So it is, presumably, with monopoly. The profits generated by monopoly pricing will encourage firms to expend resources on becoming monopolists. The expenditure of resources will continue to the point at which the expected value of monopolizing, less the costs of obtaining a monopoly, is equal to the next most profitable use of these resources. ${ }^{16}$ Therefore, as a first approximation, the cost of monopoly in the left-hand diagram of Figure 1 is equal to the entire hatched area. ${ }^{17}$

a socially valuable by-product; a good example is innovation that results in the issuance of a valid patent. I discuss expenditures of that sort separately below.

15 See Becker, Crime and Punishment: An Economic Approach, 78 J. Pol. Econ. 169 (1968); Tullock, The Welfare Costs of Tariffs, Monopolies, and Thefts, 5 W. EcoN. J. 224 (1967).

16 The effect of monopoly in deflecting revenues from other activities into monopolizing has long been recognized in the analysis of patents. See G. STIGLER, The Organization of Industry 124 (1968); Plant, The Economic Theory Concerning Patents for Invention, 1 ECONOMICA (n.s.) 30 (1934).

17 With diminishing returns to obtaining a monopoly, the total cost of monopoly will be lower than the total revenue since marginal cost will be higher than average cost, as shown in Figure 2: 
The right-hand diagram depicts a monopolist who, facing the same cost and demand conditions as the monopolist in the left-hand diagram, perfectly and costlessly discriminates in price. Every sale is made at a price equal to the value that the consumer places on the purchase, and no cost is incurred in ascertaining those values and dealing separately with each consumer over each unit of output. The effect of such discrimination is to increase the profits of the monopolist to an amount measured by the entire area between the demand curve and the mar-

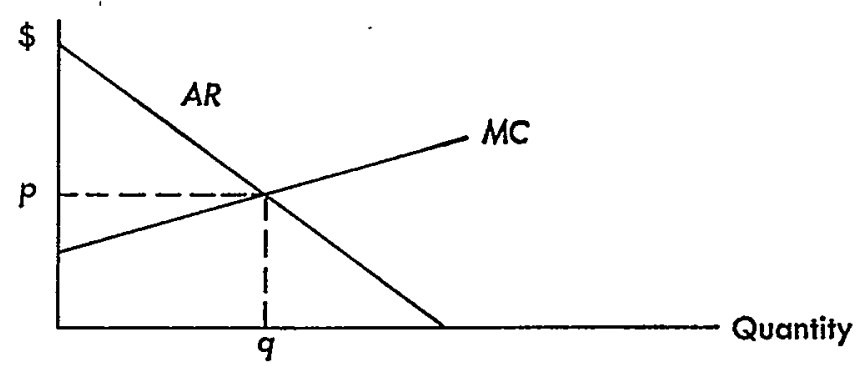

FIGURE 2

$A R$ is the average revenue from monopolizing, and $M C$ the marginal cost of becoming a monopolist. The difference between the total revenues from monopolizing $(p q)$ and the total marginal costs of monopolizing (the area under $M C$ between the origin and $q$ ) is economic rent earned by resources specialized to monopolizing. This rent is not a social cost.

Ignoring this point (i.e., assuming constant returns to scale in monopolizing), we can easily express the relationship between the traditional deadweight loss of monopoly $(D)$ and the additional loss $(L)$ generated when firms expend resources on becoming monopolists. $D$ in Figure 3 is simply $1 / 2\left(P^{\prime}-P\right)\left(Q-Q^{\prime}\right)$, while $L$ is $\left(P^{\prime}-P\right) Q^{\prime}$. The ratio of $L$ to $D$

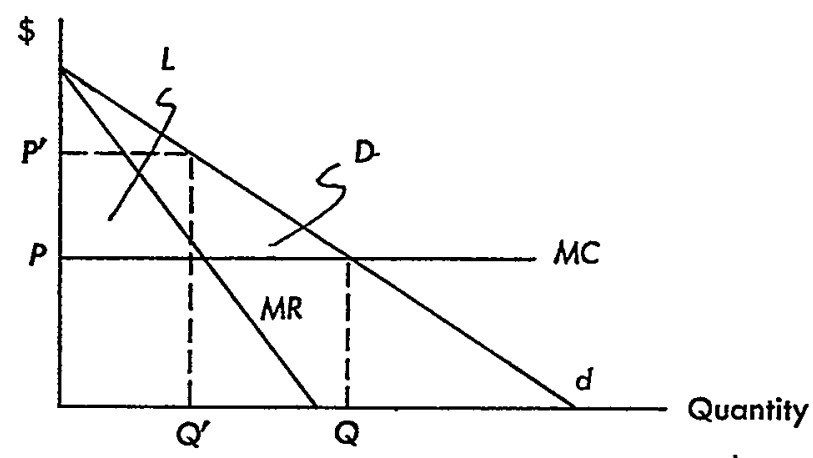

FIGURE 3

is, therefore, simply $2 Q^{\prime} / Q-Q^{\prime}$. Thus, where the percentage reduction in output brought about by monopolizing is small, the deadweight loss of monopoly is only a small fraction of the additional loss. For example, if $Q=100$ and $Q^{\prime}=95$ (meaning that monopolization has resulted in a 5 percent reduction in output), $L$ is 38 times as large as $D$. For a full development of this analysis and some empirical results see $R$. Posner, The Social Costs of Monopoly and Regulation, May 1974 (unpublished paper). 
ginal cost curve, hatched in the diagram, and to eliminate the deadweight loss. The hatched area in the right-hand diagram is larger than the hatched area in the left-hand diagram, implying that the social cost of monopoly is higher under perfect price discrimination than under single-price monopoly, even though the conventional deadweight loss is zero. In addition, under discrimination, purchasers pay different prices for the same product that are unrelated to cost differences, thus distorting competition among them.

The conclusion that price discrimination increases the social costs of monopoly holds even if we relax the unrealistic assumptions that discrimination is perfect and costless. If discrimination is not perfect, and it never is, the effect on the monopolist's output and hence on the deadweight loss of monopoly becomes an empirical question that will be answered differently from case to case: the output may be larger than, smaller than, or the same as the output under a single monopoly price. ${ }^{18}$ If the only difference between perfect and imperfect price discrimination were that the latter involved deadweight loss, our earlier conclusion would be unambiguously strengthened. An additional difference, however, is that imperfect discrimination is less profitable. Thus, the deadweight loss is less under perfect than under imperfect price discrimination, but the monopoly profits, and hence the costs that will be incurred to obtain the monopoly, are greater under perfect discrimination.

The fact that discrimination is costly to implement increases the social costs of a discriminating monopoly relative to those of a singleprice monopoly. The costs of implementing discrimination represent a net social loss, because these costs do not, on the average, produce social benefits. One can imagine cases in which the sum of (1) the additional costs of monopolizing due to the higher profits from discrimination and (2) the costs of discriminating could be less than the benefits, represented by a reduction in deadweight loss, that the discrimination might produce; but there is no reason to think that such cases are common.

The major qualification to the foregoing analysis is that if society wants to increase the amount of monopoly-for example, in order to spur invention-the effect of higher monopoly profits in inducing more monopolizing may count as a social gain instead of a social loss. This observation is relevant to the many cases in which tie-ins have been imposed by firms owning patents in order to increase their profits from the patented invention. If one thought that the patent laws tended to undercompensate inventors, resulting in a suboptimal rate of innova- 
tion, one might want to encourage price discrimination in order to increase the amount of investment in inventive activity. Unfortunately, no one has any idea whether the nondiscriminatory exploitation of patents would result in too much, too little, or the right amount of invention. ${ }^{19}$

The main point of this discussion is that reclassifying tie-ins from an exclusionary practice to a form of price discrimination, or unilateral noncoercive monopolizing, does not establish that they ought to be permitted by the antitrust laws. There is, however, a serious objection to prohibiting tie-ins. Given the absence of any general and uniform prohibition against discrimination, the prohibition of tie-ins is trivial; the monopolist will merely adopt another, and lawful, method of discriminating. ${ }^{20}$ This raises the question, which $I$ cannot hope to resolve here, whether there should be a general prohibition of price discrimination. ${ }^{21}$ The common argument that such a prohibition would merely treat a symptom of monopoly, rather than monopoly itself, is unpersuasive. If the previous analysis is correct, and discrimination is a source of net social costs, an effective and inexpensive prohibition would increase economic welfare. A more serious objection to prohibiting price discrimination is that it is often a by-product of movement from one equilibrium to another-sometimes from a monopolistic to a competitive equilibrium-and prohibiting it would impede such movements. Moreover, discrimination is difficult (costly) to prove; the Robinson-Patman

19 See W. Bowman, JR., supra note 1, at 15-31.

20 Of course, if all of the other methods are much costlier or much less effective, the amount of discrimination may be significantly reduced, which by the previous analysis would generate social cost savings. This assumption, however, seems implausible, since use can be metered directly as well as by a tie-in.

21 That the law contains such a prohibition is suggested in Commissioner Elman's concurring opinion in Peelers Co., 65 F.T.C. 799, 865-69 (1964), discussed approvingly by the court of appeals that reviewed the Commission's decision. LaPeyre v. FTC, 366 F.2d 117 (5th Cir. 1966). The patentee of the only process for cleaning shrimp by machine leased the machine at a higher price to Pacific Northwest shrimpers than to Gulf Coast shrimpers because the costs of cleaning by hand were higher for the former group. The result was to perpetuate a cost difference between competing segments of the industry that the development of machine cleaning, in the absence of discrimination, would have eliminated.

Commissioner Elman cited as precedent for his view that a monopolist has a duty to refrain from discrimination United States v. Terminal Railroad Ass'n, 224 U.S. 383 (1912), but that case is distinguishable because the targets of the discrimination there were competitors of the discriminating firms rather than customers. Although discrimination against a competitor was alleged in the Peelers case, and found by the Commission, Commissioner Elman rejected this finding in his opinion.

A narrow interpretation of the result in Peelers is that it was a case in which section 5 of the Federal Trade Commission Act, 15 U.S.C. $\$ 45$ (1970), was used to plug a loophole in the Robinson-Patman Act; the discrimination there was effected through a lease rather than a sale. 
Act is a testament to the problems of attempting to regulate discrimination.

I do not want to leave the impression that discrimination is the only form of unilateral noncoercive monopolizing. For example, Professor Coase has argued that the lease-only policy of a monopolist of a durable good, such as United Shoe Machinery Corporation, may be designed to overcome the difficulties encountered in trying to charge a monopoly price for a durable good. ${ }^{22}$ Perhaps the lease-only policy should have been forbidden on that ground, but this paper will argue that, as with tie-ins, the lease-only policy is not exclusionary.

\section{The Exclusionary Practices}

\section{A. Predatory Pricing}

Within the class of allegedly exclusionary practices, it is useful to distinguish practices that require the cooperation of a customer to be effective from those that do not. Predatory pricing depends on the purchasers' willingness to buy from the predator (or the intended victim) at the predatory price; blowing up a competitor's plant or procuring a patent from the Patent Office by fraud does not. This distinction is important to our analysis, although less important regarding predatory pricing than some of the other exclusionary practices.

Suppose that the Standard Oil trust reduces its price in one market below cost, hoping to drive out its competitors there and later raise its price to a monopoly level. Presumably it expects its eventual monopoly profits, discounted to present value, to exceed the losses from selling below cost now. This assessment must assume, however, that the average purchaser in this market will sustain a net loss by paying a subcompetitive price to Standard, instead of a higher price to a competitor of Standard. ${ }^{23}$ The lower price he pays now will be more than offset by the higher price he will pay later when Standard, with his help, obtains a monopoly. The purchaser would be better off continuing to patronize Standard's nominally higher-priced competitor.

This point seems to have been overlooked in discussions of predatory pricing; but, while relevant, the point is not decisive on the question of whether predatory pricing is a rational business strategy absent legal sanctions. The argument assumes that the purchaser (1) is sufficiently informed and far-sighted to realize the cost to him of taking advantage of the temporarily lower price and (2) will not act as a "free rider,"

22 Coase, Durability and Monopoly, 15 J. LAw \& Econ. 143 (1972).

23 It is irrelevant how long the purchaser, if it is a firm, expects to remain in the market; the higher price in the future will adversely affect the firm's market value. 
taking advantage of the lower price in the hope that the refusal of other purchasers to do so will cause the predator's campaign to fail. These assumptions are unrealistic in some market settings, particularly when there are many purchasers.

An extensive literature ${ }^{24}$ seeks to show on other grounds that predatory pricing is not an effective method of monopolizing. That literature, however, has been excessively influenced by John McGee's pathbreaking article on the use, or rather the nonuse, of predatory pricing by the Standard Oil trust. ${ }^{25}$ Ever since that article appeared, scholars have stated the question of predatory pricing as whether it was rational for the Standard Oil trust to practice such pricing. The answer has been negative, because it is cheaper to acquire than to undersell a competitor. But this answer is convincing only if mergers are assumed to be legal, and although this assumption was reasonable throughout most of the history of the Standard Oil trust, the illegality of mergers to create a monopoly has now long been settled. Predatory pricing is also illegal, but it is more difficult to detect than mergers. Thus, given the legal environment, predation may in fact be a cheaper method of monopolization than acquisition. ${ }^{26}$

This possibility does not, of course, make predation an effective method of monopolization. To impose costs on a competitor by imposing the same or greater costs on oneself does not look like a very promising method of excluding a competitor. If, however, a firm operates in a number of markets and faces actual or potential competitors that are each limited to one of its markets, it may be worthwhile for it to expend large resources on crushing a single competitor so as to develop a reputation for willingness to use predatory pricing. Such a reputation would enable the firm to exclude other potential competitors without additional below-cost selling; stated otherwise, the costs incurred by the firm in using predatory pricing in one market might generate offsetting benefits in other markets. Knowing that the dominant firm might act in this way, a competitor might be reluctant to enter

24 Most of the literature is cited in Yamey, Predatory Price Cutting: Notes and Comments, 15 J. LAW \& EcoN. 129 (1972).

25 McGee, Predatory Price Cutting: The Standard Oil (N.J.) Case, I J. LAW \& EcoN. 137 (1958).

26 Moreover, even if predation were always cheaper than acquisition, it would not follow that it was nonexistent. Settlement is cheaper than litigation as a method of resolving legal disputes, yet one observes litigation occurring. The basic reason is that the parties to a dispute may have divergent expectations regarding the likely outcome of litigation, which may make it impossible for them to agree on a mutually advantageous settlement price. Similarly, competing firms might not be able to agree on a mutually advantageous price for the sale of one firm's assets to the other. In such circumstances, predation might be the only method of achieving a monopoly. 
any market in which the firm operated, and if he was already in such a market he might refrain from price competition or agree to sell out to the dominant firm at a low price. On this analysis, the threat of predatory pricing might have been effectively used by the Standard Oil trust, because it operated in more markets than many of its actual and potential competitors. ${ }^{27}$ If the threat was effective, actual predatory pricing may have been unnecessary; moreover, an implicit threat may have been sufficient. In either case, McGee's study of the record in the Standard Oil case might not have uncovered the extent to which Standard owed its market position to predatory tactics. ${ }^{28}$

Thus, to conclude that predatory pricing is never an effective exclusionary practice is unsupportable-whether or not the predator is assumed to have superior access to capital. However, our analysis implies that predatory pricing at most is likely to delay, rather than prevent, the entry of new competitors. It is unlikely that a firm planning to enter all of the markets of the dominant firm would be deterred by fear of predatory pricing. In those circumstances the benefits of predatory pricing are unlikely to exceed the costs, since the costs must be incurred in every market in which the predator operates; hence, the dominant firm will find it difficult to make a credible threat to engage in predatory pricing. Probably the only long-run consequence of predatory pricing, therefore, is to increase the scale of new entry. This result may lengthen the time that it takes for entry to occur-as will be seen, more time may be required to organize a large operation than a small onebut it should not entirely preclude entry. The need to enter on a larger scale does not increase the costs of the new entrant relative to those of the existing firm, since the latter also operates on the larger scale. Any diseconomies caused by operating in so many markets are also experienced by the existing firm.

Any factor that delays entry prolongs the period of monopoly pricing and thereby increases the social costs of monopoly. The increase in these costs, however, may not be large. A commonly overlooked point is that an increase in the time required for new entry may actually make entry more attractive to some firms; they may anticipate a longer period before any supracompetitive profits that they are able to obtain in the market disappear due to competition from additional entrants.

What are the implications for legal policy of a correct economic analysis of predation? This paper has argued that the case for relegating

27 Cf. Posner, An Economic Approach to Legal Procedure and Judicial Administration, 2 J. Legal Studies 399, 432-33 (1973).

28 In addition, the fact that a practice is not uncovered by the lawyers for a party to a lawsuit is not very compelling evidence that the practice did not exist. 
predatory pricing to the realm of the irrational has not been made. Even if it had been made, as many economists believe, it would not follow that the prohibition against predatory pricing should be removed. To be sure, the costs of the prohibition may be high because predatory pricing is not easy to distinguish from other forms of price competition. At the same time, however, the prohibition has some positive benefits even under the assumption that predation is never rational profit-maximizing behavior. The correct level of an activity is achieved by compelling actors to bear the full social costs of their actions, including mistakes; the predator's losses may not equal those costs. This possibility is clearly raised when predation succeeds to the extent that the period of below-cost pricing is followed by one of supracompetitive pricing. The social costs incurred in each period are additive. The misallocative effects of selling a product below cost, thus inducing ineffcient substitution towards it, are not reduced by subsequently selling the product at a monopoly price, thus inducing inefficient substitution away from it. The private costs of predatory pricing are thus lower than the social costs, because the period of monopoly pricing compensates the seller, though by hypothesis not fully, for the losses he incurred when he sold the product below cost.

That forbidding predatory pricing would be a source of some social benefits-either because predation is sometimes a rational practice or because, though irrational, it would be practiced occasionally by firms that misconceived their self-interest-does not mean that such a prohibition is wise. That depends on the costs of the prohibition in relation to its benefits. Those costs are substantial because of the difficulty of distinguishing between predatory and efficient pricing.

There are two conventional approaches to the identification of predatory pricing, one through intent and the other through cost. Neither is adequate. If the forbidden activity is defined as pricing intended to weaken or destroy a competitor, too much is forbidden. A seller may want to destroy a competitor, but if the only method used is underselling because of lower costs there is no rational antitrust objection. And too little is also prevented. Intent may be impossible to prove; further, inadvertently pricing below cost could be just as injurious and inefficient as pricing below cost with intent to exclude competitors. Alternatively, if predatory pricing is defined as pricing below cost or as discriminatory pricing, we may forbid too much, depending on how we define cost or discrimination; or, as we shall see, we may forbid too little.

It would seem that only two practices should be forbidden as predatory or (a better term perhaps) exclusionary pricing. The first is selling 
below short-run marginal cost. There is no reason consistent with an interest in efficiency for selling a unit at a price lower than the cost that the seller incurs by the sale. We expect the clothing store to sell last year's fashions at a drastic discount-its price may even be lower than what it paid for the goods-but not at a price lower than the cost of making the sale, which includes any profit it might have expected from charging a higher price. A sale below cost in this sense can only have the purpose and effect of excluding an equally or more efficient rival. Unfortunately, measurement problems make this category of forbidden practice difficult to use; for example, how does this legal rule treat the case in which a firm offers goods below cost as a method of sales promotion? The true sales price can be calculated only by including any future revenues generated by the sale-other than revenue produced by monopoly pricing. ${ }^{29}$ The difficulties of measurement seem forbidding, given the present state of economic science.

The second practice that should be forbidden is selling below longrun marginal cost with the intent to exclude a competitor. Long-run marginal costs are those that must be recovered to stay in business for the more or less indefinite future. In a retail store they include the rent, insurance, other overhead costs, and the cost of inventory. If the retailer's total revenue is not large enough to cover all of these costs, he will eventually be forced out of business. Selling below long-run marginal cost, however, is not conclusive evidence of socially inefficient pricing. Some businesses, or parts of businesses, have no future. No social purpose is served by forcing a seller to include in his price a charge for the depreciation of a plant that will never be replaced. In these circumstances, charging a price below long-run marginal cost does not imply an exclusionary intent or effect. On the contrary, the purpose and effect are to make a graceful — cost-minimizing —exit, leaving the field to more efficient firms.

If there is intent to exclude, however, pricing below long-run marginal cost will have the purpose and likely effect of excluding an equally efficient competitor-equally efficient because if the "predator" is more efficient he can and will exclude his competitor by charging a price equal to or higher than his own long-run marginal costs. Again, measurement problems abound; in particular, the assignment of marginal costs to an individual product or market will often be quite arbitrary.

29 Even the qualification must be qualified. A firm might dispose of some of its output below cost in one market in order to limit its output, and thereby increase its prices and profits, in another market, where it had a monopoly. Such "dumping" may be objectionable, but not on the ground of tending to exclude competitors in the market where the dumping occurred. 
Moreover, the need to rely on evidence of intent is a disturbing feature of this approach, especially to economists, whose assumption is that people's actions yield better insight into their true purposes than what they say. An alternative approach, which seems, however, to be beyond the present capacity of economic science, is to examine the full range of possible reasons for a particular pricing policy and to infer predation only after rejecting all other possible reasons for selling below marginal cost (declining demand, obsolete plant, and the like) as implausible in the circumstances of the case.

A short cut to finding predation that seems even less appropriate than requiring proof of sales below marginal cost plus exclusionary intent is requiring proof of price discrimination plus exclusionary intent. If the alleged predator's price is above his long-run marginal costs in the relevant market, it is irrelevant that he is charging a higher price elsewhere, where he faces less competition; his lower price in the relevant market can exclude only a less efficient competitor-one whose longrun marginal costs are higher than the defendant's. By linking exclusionary intent and area price discrimination, while ignoring the relationship between price and long-run marginal cost in the relevant markets, the Supreme Court reached an anticompetitive result in Utah Pie Co. v. Continental Baking Co. ${ }^{30}$ The defendants were charging lower prices in markets in which the plaintiff competed than they were charging in some other markets. The Court cited no evidence of sales at a price below long-run marginal cost. ${ }^{31}$ Intent to weaken Utah Pie was shown, but that evidence was neither surprising nor disreputable considering that Utah Pie, rather than any of the defendants, was the dominant firm in the markets involved.

Another indefensible predatory pricing case is Telex Corp. v. IBM Corp. ${ }^{32}$ in which a district court found that IBM had made drastic price reductions in equipment that was "plug-compatible" with its main-frame computer equipment in order to repel the competitive inroads made by Telex, another producer of equipment plug-compatible with IBM computers. The court held the price reductions unlawful, emphasizing that (I) IBM was the dominant firm in the relevant market (oddly and inaccurately defined as the sale of equipment plug-compatible with $I B M$ computers); (2) the price reductions reduced IBM's net revenue from sales of the products in question; (3) the reductions were not cost justified; and (4) IBM's purpose was to weaken Telex.

30386 U.S. 685 (1967).

31 The Court did state that one of the defendants was not recouping its "full overhead," id. at 698-99, but it did not suggest that the amount of overhead foregone was a long-run marginal cost of selling in Utah Pie's markets.

32367 F. Supp. 258 (N.D. Okla. 1973). 
This evidence, however, is consistent with the hypothesis-neither mentioned by the court nor, apparently, argued by either party, but one that fairly leaps to the eye-that IBM was adjusting in a natural and socially appropriate manner to the erosion of its monopoly position because of Telex's entry into the market. IBM began with 100 percent of the relevant market; even though the court incorrectly defined the market, we may assume that IBM had some monopoly power and that its price exceeded its cost. Telex's advent provided competitive alternatives to IBM's customers. As a result the demand curve facing IBM became more elastic, the profit-maximizing monopoly price fell, and IBM lowered its price. The price reduction was not cost justified; it was a reaction to a change in demand, rather than a change in cost, and the final price may still have exceeded IBM's long-run marginal cost. IBM's net revenues in the relevant market fell, because Telex's entry was an adverse development to which IBM reacted by attempting to limit its losses. These losses would have been greater if IBM had permitted Telex to take the entire market, but IBM could not hope to increase its revenues above what they would have been if Telex had not entered the market. A monopolist's profits must fall if the demand for his product becomes more elastic as the result of, for example, new entry.

The effect of the court's approach in Telex is to force a dominant firm to operate at a price higher than the monopoly price; the firm is prohibited from closing the umbrella of high, monopoly prices that encouraged firms like Telex to enter its markets. This result is perverse and would have been avoided if the court had used the two-part test of predatory pricing suggested above. There are grave doubts, however, about the feasibility of that test. One is left wondering whether any rule against predatory pricing can be justified in light of the costs of administering such a rule.

Nevertheless, if some rule against predatory pricing is to be retained, the question arises: who should enforce the rule? Should it be the government, the predator's competitors, or both in some combination? Private enforcement is a realistic possibility in this area, because the principal victims of predation are firms having a sufficiently large stake to be motivated to sue.

If the only concern were maximizing the utility of a fixed budget for public antitrust enforcement, then enforcement of the antitrust laws clearly should be left to private plaintiffs in areas in which they have strong incentives to sue, such as predatory pricing. But such a concern is too narrow. It is also necessary to consider the costs of private antitrust enforcement; the major cost is the distortion of doctrine. 
It may be a coincidence that both Utah Pie and Telex were private cases. No one has done a systematic study of the contribution of the private action to antitrust doctrine; indeed, it may be too soon to do so, since the rise of the private action to a position of importance in the enforcement of the antitrust laws is very recent. For what it is worth, my impression-shared by many other students of antitrust law-is that private antitrust cases tend to deviate from fundamental antitrust policy more than Department of Justice antitrust cases. Why might this be so?

The rules of antitrust law are produced mainly by Congress and the Supreme Court, ${ }^{33}$ and the costs to each institution of producing these rules are very high. ${ }^{34}$ Legislative enactment is a costly method of production, because it entails negotiation among many parties (the legislators) and because the productive capacity of a legislature is inherently limited since expansion of its membership increases the costs of each enactment. Therefore, assuming that detailed and specific legislation is more costly to produce than general and vague legislation, one can expect legislated antitrust rules to be vague and general. Rule production by the Supreme Court does not involve the costs of large-number negotiations, because there are only nine Justices. But the Court has a heavy, extremely diverse workload that limits the time it can effectively allocate to learning the facts of a particular case and drafting a careful opinion in an area so complex and technical as antitrust law.

As a result of these factors, the body of antitrust rules does not implement with precision the basic purposes of the antitrust laws; what is forbidden does not exactly fit what was intended to be forbidden. The relevant part of the misfit here is the rules' overinclusiveness: they forbid, or can be read as forbidding, conduct that is not actually anticompetitive. The rules could be too narrow as well as too broad, but it is not important, for the present argument, to show that the antitrust rules are systematically overinclusive. ${ }^{35}$ The only fact essential to the argument is that the rules contain some overbroad or overinclusive elements.

One effect, and perhaps a purpose, of a public monopoly of law enforcement is to limit the effect of overbroad rules. The Supreme Court can state-as it virtually has-that all horizontal mergers violate sec-

33 The Expediting Act, 15 U.S.C. \& 29 (1970), which authorizes direct appeal from the federal district courts to the Supreme Court in antitrust cases brought by the Justice Department, has reduced the role of the courts of appeals.

34 The theoretical basis for the following discussion is presented in Ehrlich \& Posner, An Economic Analysis of Legal Rulemaking, 3 J. Legal Studres 257 (1974).

35 "It seems, however, that the rules are indeed systematically overinclusive for reasons that are not well understood. 
tion 7 of the Clayton Act. ${ }^{38}$ If enforced, such a rule would impose heavy social costs; and the rule might be enforced if private enforcement is permitted. The Supreme Court (or Congress) then might have to incur heavy $\operatorname{costs}^{37}$ in retracting its statement and formulating a more careful rule of law. The alternative is a public monopoly of enforcement. The Justice Department will not enforce a rule banning all horizontal mergers, because it lacks the resources to bring every case that falls within the careless language of Supreme Court opinions. ${ }^{38}$ With a public monopoly of enforcement, legislative enactment becomes a twostage process. The legislature first enacts the statutory standard and later appropriates funds to the enforcement agency. The appropriation determines the scope of enforcement-the operational meaning of the statute-since the smaller the appropriation, the more selective the agency must be. The agency might select the silliest cases first, but there is no basis in theory or experience that indicates it would. ${ }^{30}$

This analysis is suggestive, but not completely convincing. ${ }^{40}$ Its implications reach far beyond the question whether private parties should be permitted to bring predatory-pricing cases. The analysis thus far, however, is incomplete; in comparing private and public enforcement of antitrust law we have not exhausted the possible alternative methods of dealing with exclusionary practices. The analysis will be expanded after discussing the remaining exclusionary practices.

\section{B. Vertical Mergers}

If a firm purchases a customer or a supplier and directs the acquired company to deal only with the firm, the market for its competitors' goods, or its competitors' access to inputs, will be reduced. The same effect can be achieved by opening a new outlet and channeling all sales through the outlet, ${ }^{41}$ but there are few cases in which vertical integration through internal expansion, instead of acquisition, has been chal-

3615 U.S.C. \$ 18 (1970). See United States v. Von's Grocery Co., 384 U.S. 270 (1966). But cf. United States v. General Dynamics Corp., 94 S. Ct. 1186 (1974).

37 On the difficulty of reducing the Court's workload to free the Justices' time for more careful decision-making, see Casper \& Posner, A Study of the Supreme Court's Caseload, 3 J. LeGAL STudIES (1974) (forthcoming).

38 Compare Department of Justice Merger Guidelines, pt. I, 1 TrAde Reg. Rep., pt. I, If 4510, at 6883-85 (1968), with United States v. Von's Grocery Co., 384 U.S. 270 (1966).

39 Cf. Posner, The Behavior of Administrative Agencies, 1 J. LEGAL Studies 305 (1972), reprinted in The Economics of CRIME AND PUnishment 216 (G. Becker \& W. Landes eds. 1974).

40 Among other things, it does not explain why the Federal Trade Commission's antitrust decisions have generally been more anticompetitive than those of the Justice Department.

41 See Peltzman, Issues in Vertical Integration Policy, in PUblic Policy Toward MercERS 167, 175-76 (J. Weston \& S. Peltzman eds. 1969). 
lenged under the antitrust laws. The exclusionary effect of a vertical merger is similar to that of a contract between a firm and a customer or supplier whereby the latter agrees to deal exclusively in the firm's goods, but there are enough differences between the contract and merger methods of exclusive dealing to warrant separate treatment.

Imagine an industry with two levels, production and distribution. If production is monopolized and distribution is competitive, can the monopolist increase his profits by buying out the distributors? The analysis is parallel to that of tying. If the producer acquires the distributors and increases the retail markup, he will have to decrease his producer's markup by the same amount. He cannot maximize his profits by charging a price above the monopoly price determined with reference to all relevant costs, including the cost of distribution. It is also necessary, however, to consider the possibility that the acquisition of the distributors will delay new entry at the production level by making it necessary for a new entrant to enter at both the distribution and production levels. ${ }^{42}$ We brushed aside a similar argument with respect to tying arrangements by observing that the tied product is usually a trivial adjunct to the tying product, ${ }^{34}$ but the argument has greater appeal in the present context.

A firm's cost of production is inversely related to the time interval between the decision to produce and the delivery to the purchaser of the output. ${ }^{44}$ Since increases in the interval reduce the present value of the firm's output, as well as the cost, the firm will not delay production and delivery indefinitely. The optimum delay will depend in part on the rate at which cost falls with delay, and one imagines that the rate will be higher for more complicated production processes. This relationship may explain why U.S. Steel's monopoly position was not eliminated immediately after creation by the entry of new firms or the expansion of existing firms: the cost of quickly creating, or rapidly expanding, a complex enterprise such as steel production is prohibitively high. ${ }^{45}$ Consider the contrasting position of a firm that buys up

42 Delay, rather than prevent, because the new entrant's costs would be no higher than the existing firm's; each would have costs of distribution and production. See text following note 28 supra.

43 See text at notes 11-13 supra.

44 Alchian, Costs and Outputs, in Readings in Microeconomics 159, 165 (W. Breit \& H. Hochman eds., 2d ed. 1971).

45 This answer is not completely satisfactory, since it does not explain why the formation of U.S. Steel was not anticipated far enough in advance to enable competing firms or new entrants to complete their preparations for expansion by the time U.S. Steel was formed; perhaps its formation was too uncertain to induce the investment necessary to enlarge the capacity of firms not included in the merger. 
all of the grocery stores in a town and begins to charge monopoly prices. Even if the monopoly is completely unanticipated, the creation of additional grocery stores will take only a short time, because the activities that must be coordinated in order to open a new grocery storeobtaining suitable premises, hiring the necessary personnel, financing, and arrangements with suppliers and customers-are few and simple.

The discussion thus far has assumed that, if the existing producer owns all of the distribution outlets, a new entrant into production would have to open distribution outlets. This assumption, however, is not necessarily true; if entry into production is anticipated, new firms will enter at the distribution level in order to provide a market for the new producers. But this anticipation merely converts explicit coordination into implicit coordination. A new firm will not enter at the production level until it is reasonably confident that it will have distribution outlets, and new firms will not enter into distribution until they are reasonably confident that there will be producers to supply them. The parallel entry of the new producer and the new distributors could take longer than entry at one level.

In sum, the monopoly producer's acquisition of the existing distribution outlets could delay new entry into production, and this delay would tend to increase the monopoly price. It is also possible that having to enter at the distribution level might increase the costs of the new producer relative to those of the existing firm by increasing the risk premium charged by the suppliers of capital to the new entrant.46 This factor is independent of the new entrant's choice between creating his own distribution outlets and awaiting the entry of new distributors, since any risk premium charged the latter is an indirect cost of production.

Although the monopoly producer derives benefits from acquiring all of his distributors, he also incurs costs. ${ }^{47}$ The acquisition will only delay entry, rather than preclude it, and when entry does occur the producer who owns all of the existing distribution outlets and refuses to carry his competitors' goods will find himself with excess distributive capacity, because he will lose some business to the new entrant. This loss will increase his average costs and decrease his profits compared to what they would have been with a smaller investment in distribution. If the market is growing, the monopolist can avoid this result by adding new distribution outlets more slowly than necessary to provide distri-

46 Williamson, Book Review, 83 Yale L.J. 647, 658 (1974) (review of W. Bowman, supra note 1). A similar argument is made in Peltzman, supra note 41 , at 173 .

47 This point is stressed in Peltzman, supra note 41, at 169-70. 
bution for the entire market, but this course of action would mean that there will be distributors for the new entrant's goods when he appears.

To try to delay the entry of new competitors by precluding the development of an independent distribution system involves two additional types of cost. First, the firm is likely to encounter diseconomies in integrating distribution and production. Integration for the purpose of exclusion implies that there are no economies of integration; if there were, there would be an independent and socially acceptable ground for integration. Second, if the firm has a policy of monopolizing distribution, people may start distribution outlets for the sole purpose of being bought out by the firm-a form of lawful extortion. To combat such extortion the acquiring firm may have to resort to predatory pricing, also a costly measure.

Imagine now that there are two producers, each with 50 percent of the market, and one decides to eliminate the other by buying all of the distribution outlets and then terminating their purchase of competing products. The other producer will respond by opening his own outlets, or independent firms will open them. In the end, the first producer will own twice as many outlets as he needs for his output, and his average costs of distribution will be about double those of his competitor. This tactic is not a recipe for monopolization.

If, for some unlikely reason, it is impossible to create new distribution outlets, the analysis resembles that of predatory pricing. The existing distributors are the producers' only customers, and the only possible response by the second producer to the first producer's offer to acquire the distributors is to match the offer. If the first producer can somehow succeed in obtaining control of distribution, and with it a monopoly of production, the price of control will be high. The minimum price for the distributors' assets will be the costs to the second producer of being forced out of business; the second producer will pay any price up to that cost in order not to be forced out.

What are the implications of this analysis of vertical acquisition for legal policy? Although it is unlikely, a monopolist might acquire its distributors, other customers, or suppliers in order to hinder new entry. It is improbable, however, that a firm in a competitive industry would acquire a customer or supplier because of an exclusionary motive; even for our firm with 50 percent of the market, the acquisition of distributors was an implausible method of excluding competition.

Now consider the case in which all or most of the firms in a competitive industry are acquiring distributors, or other customers, and, if the trend is not checked, the industry will eventually be completely integrated. New entry might be hindered, but there are two strong 
objections to a rule forbidding such vertical acquisitions. First, delaying new entry will have no effect if, as assumed, the industry is competitive; prices will be at the competitive level whether or not entry is imminent. To be sure, delaying entry may increase the gains from cartelization, making it more likely that the industry will be cartelized, but this prospect seems too remote to support a prohibition. ${ }^{48}$ Second, the simultaneous movement of a number of independent producers to acquire customers or suppliers is more likely to reflect the existence of economies of integration than a purpose of hindering entry, unless the firms are already colluding. At least in an industry having more than a few firms, it is unlikely that each firm would act based on the belief that if it acquired its distributors and each of its competitors happened to do the same (so that no independent distributors remained), there would be greater opportunity for profitable collusion, because the threat of new entry would be lessened. Since there are motives for mergers unrelated to the desire to monopolize or the economies of integration, one cannot be certain that a series of vertical mergers proves the existence of substantial economies of vertical integration in an industry. It is more likely, however, to reflect economies than collusion.

The conclusion is that a rule against vertical mergers is untenable, except possibly when one of the parties to the merger already has a monopoly. Moreover, it is not at all clear how to design an appropriate rule even for that limited case. It would be absurd to forbid a monopolist to be vertically integrated; literally construed, this rule would mean that the monopolist was required to contract out all stages of the production process. The rule would have to be limited to "unnecessary" integration-integration not justified by efficiency, but adopted in order to hinder entry. Such a rule would be even harder to apply concretely than the parallel rule suggested in the predatory-pricing area.

\section{Exclusive Dealing}

In our original vertical merger example, the monopoly producer, instead of buying the distributors and forbidding them to sell to any newcomer, could have entered into contracts with the distributors whereby the latter would agree not to handle the goods of a competing producer. Whether such a contract has any exclusionary effect depends on its duration. If the contract is terminable on short notice, as in the

48 The effect of vertical integration in shoring up a cartel by reducing the opportunity for cheating, explained in Posner, A Program for the Antitrust Division, $\$ 8$ U. CHI L. REv. $500,516 \&$ n.48 (1969), would also appear to be too small to justify prohibiting vertical integration. 
Standard Stations case, ${ }^{49}$ the exclusionary effect.will normally be zero, since the distributor is free to take on a new supplier at any time. The only exception to this general rule occurs when there are such economies of scale in distribution, or efficiencies in distributing a variety of products at the same outlet, that a distributor forced to choose between handling only the goods of the existing seller and only the goods of a small new firm-the choice forced upon him by the exclusive-dealing contract-will always choose the former. ${ }^{50}$ The effect is merely to increase the scale necessary for new entry, but by our earlier analysis this effect will also increase the time required for entry.

The exception is inapplicable to Standard Stations, the leading precedent on exclusive dealing. The distributors in that case were retail gasoline dealers. A new entrant into the production of gasoline would have had no trouble obtaining retail outlets, because service stations find it uneconomical to handle more than one brand of gasoline. ${ }^{51}$ Nevertheless, the Court invalidated the exclusive-dealing contracts between a supplier and the retail dealers.

Even if we assume an exclusive-dealing contract of indefinite or very long duration, the use of exclusive dealing as a method of exclusion seems even less likely than the use of vertical mergers for this purpose. ${ }^{62}$ The distributor who sells his business is indifferent to the amount of competition that remains in the market; he is out of it. But the distributor who agrees to carry the goods of only one producer as part of a scheme to give that producer a monopoly will be uneasy. Once the producer achieves a monopoly, the distributor will be at his mercy, unless the contractual terms prevent the producer from later charging him a monopoly price or compensate him for the future exactions. If the distributor insists on such terms, however, the producer will never obtain any monopoly profits from driving out his competitor.

This shortcoming of exclusive dealing as a method of monopolization is illustrated by the second United Shoe Machinery case. ${ }^{53}$ United, which had a virtual monopoly of the production of shoe machinery, refused to sell its machines to customers (shoe manufacturers); it would

40 Standard Oil Co. v. United States, 337 U.S. 293 (1949).

50 Standard Fashions Co. v. Magrane-Houston Co., 258 U.S. 346 (1922), may have been such a case. See Director \& Levi, Law and the Future: Trade Regulation, 51 Nw. U.L. REv. 281, 293 (1956).

51 Despite the Court's invalidation of exclusive-dealing contracts in the gasoline industry, multibrand stations remain rare.

52 It may, however, lessen the problem of diseconomies of vertical integration.

53 United States v. United Shoe Mach. Corp., 110 F. Supp. 295 (D. Mass.), aff'd per curiam, 347 U.S. 521 (1953). 
only lease them, and it insisted on ten-year leases. The district court found that this policy impaired the prospects of competing producers by preventing them, during the terms of the leases, from entering the large market consisting of United's customers. There are several objections to this conclusion. One objection is that competing shoe-machinery firms would not be foreclosed, since they could always buy a shoe manufacturer; but this action could involve delay and possible diseconomies of integration not borne by United. A more forceful objection is that the competing producer could line up United customers in advance of the expiration date of their leases; every year about 10 percent of the market would be free to contract. Further, because the useful life of shoe machinery is longer than ten years, the customer would rarely be in the market for a new machine less than ten years after having purchased one; thus, a ten-year lease may not be substantially more restrictive than an unconditional sale.

The point I want to emphasize, however, is a different one. The customers of United would not participate in a campaign to strengthen United's monopoly position without insisting on being compensated for the loss of alternative, and less costly (because competitive), sources of supply. Firms often shift their purchases among competing suppliers in order to preserve competition in their supply markets.

This objection, however, entails a free-rider problem, best understood through an arithmetical example. Suppose a competing shoe-machinery manufacturer leases a machine under a lease terminable at will, for $\$ 10,000$ a year; United offers to lease a similar machine for $\$ 9,000$ a year, but insists on a ten-year lease designed to destroy competing producers and enable United at the end of the term to raise its price to $\$ 20,000$. The $\$ 9,000$ price is no bargain since the deal offered by United would impose an additional cost on the purchaser equal to the present value of the higher price in the future. If that present value is $\$ 2,000$ a year, United's offer is tantamount to charging the lessee $\$ 11,000$. Nevertheless, he might accept United's offer, figuring either that (1) other shoe manufacturers would lease from the second producer at $\$ 10,000$, keeping that producer in business and thus protecting the lessee from a United monopoly, or (2) other lessees would lease from United at $\$ 9,000$, leaving him with higher costs if he paid $\$ 10,000$ to the second producer and no advantage in the future if the second producer could not survive on his patronage alone. Although the lessee might figure either way, there is no reason to expect that he would. If people always thought in such ways, no cartel, other than one that was legally enforceable, would be even partially effective. Each member would undersell 
the cartel price, figuring that everyone else was doing so or that everyone else was selling at the cartel price; under either assumption, cheating pays.

Moreover, the second producer can overcome the free-rider problem by offering to lease equipment at $\$ 10,000$ on the condition that a specified minimum number of shoe manufacturers lease equipment from him. Each lessee would find it advantageous to enter into such a contract, rather than pay $\$ 9,000$ and accept an exclusivity condition from United, since the annual cost of the United lease is actually $\$ 11,000$.

The record of the United Shoe Machinery case indicates that United in fact offered extensive financial concessions to induce shoe manufacturers to lease equipment from United. The above analysis suggests that if United's purpose was exclusion, these concessions may have dissipated all or most of the potential monopoly profits to be gained by excluding competition. There is an alternative, nonexclusionary motive for the lease-only policy, mentioned above,,$^{54}$ and it seems a more plausible explanation than exclusion. ${ }^{55}$

To summarize, it is unlikely that a rational profit-maximizing firm will use exclusive dealing as a method of excluding a competitor, but one cannot be sure that it will never do so. Again, to formulate the correct legal rule it is necessary to relax the assumption that firms invariably adopt profit-maximizing policies. United might have decided, deliberately or through ignorance, to exclude competition at the price of foregoing all or most of its monopoly profits. If so, the implications for policy are unclear. It would be odd to punish-rather than reward - the monopolist who charged the competitive price in order to retain his monopoly. Surely punishment cannot be justified on the theory that the competitors of a monopolist have a right to insist that he facilitate entry by maintaining high prices-the curious, probably inadvertent, theory of the Telex decision. ${ }^{56}$

To be sure, an exclusionary practice that may result in the elimination or reduction of monopoly profits may also have inefficient economic consequences. Such consequences result from predatory pricing. A period of below-cost pricing, which has effects parallel to and as inefficient as monopoly pricing, is succeeded by a period of monopoly prices higher than if the monopolist had followed the dominant-firm approach,

54 See text at note 22 supra.

55 That the court's injunction against the lease-only policy did not lead to a significant erosion of United's monopoly is some evidence that there was no exclusionary effect. See United States v. United Shoe Mach. Corp., 391 U.S. 244 (1968).

56 See text at note 32 supra. 
where price is set at a level that both generates monopoly profits and attracts new entrants. ${ }^{57}$ There is no similar inefficiency, however, in the lease-only case. If United was charging the competitive lease rate because it was willing to trade monopoly profits for perpetuation of its monopoly, the efficiency of resource use was enhanced. ${ }^{58}$

Another exclusionary practice alleged in the United Shoe Machinery case was the charging of a single price for machinery and its repair. The court found that this "bundling" had retarded the emergence of an independent shoe-machinery repair industry, thereby making it more difficult for other manufacturers of shoe machinery to compete with United. United was charging its customers for repair service whether or not they utilized it, so the customer was discouraged from looking elsewhere for repair service for his United machines. According to the court, the bundling made it difficult for other manufacturers of shoe machinery to compete with United. If there were economies of scale in repair, forcing other shoe-machinery producers to arrange for repair services might increase their costs relative to those of United. Without such economies the only possible effect of the bundling would be to delay the entry of new firms into shoe-machinery production. The likelihood of these effects is not illuminated by the court's opinion.

The court also failed to deal adequately with the allegation that United practiced price discrimination as an exclusionary tactic. The ratio of price to marginal cost was found to be lower in leases of those types of United machinery for which competing producers offered close substitutes than in United's other leases. This relationship is not at all surprising. Competition would increase the elasticity of demand for United's machinery, reducing the profit-maximizing price. It is true that the market would become less attractive to other producers as the price of United's machinery decreased, but it is distinctly odd to characterize this consequence of price discrimination as exclusionary in a pejorative sense. There was no allegation of below-cost pricing, merely of variance across markets in the proportion of monopoly profit in United's prices. If United were forbidden to discriminate, this proportion would rise in those markets in which it faced competition. As in Telex, the court was telling a monopolist to hold the umbrella of monopoly prices over its competitors. As suggested above, ${ }^{59}$ it might be

57 See text following note 2 supra; Stigler, supra note 2.

58 This conclusion assumes that the only social costs of monopoly arise from monopoly pricing. If monopoly led to other sorts of social cost, such as suboptimum innovation or failure to minimize input costs, then the argument in the text would have to be modified. There is, however, no persuasive theoretical or empirical evidence that monopoly has these other effects.

50 See text and notes at notes 5-22 supra. 
possible to justify prohibiting price discrimination because of its effect on the amount of resources expended in monopolizing. It is indefensible, however, to try to justify such a prohibition on the ground that it makes entry less attractive. The effect of the discriminating firm's charging lower prices in markets in which demand is more elastic is to increase output, which is a good effect of discrimination. ${ }^{60}$

If we place the old U.S. Stee ${ }^{61}$ case alongside United Shoe Machinery and $A l c o a{ }^{62}$ the other leading monopolization decision of the modern period, we discover that the antitrust laws treat the firm that charges low, but not inefficiently low, prices in order to retain a monopoly position more harshly than the firm that seeks to maximize its monopoly profits by charging a high price. Judge Hand criticized Alcoa for expanding its productive capacity in anticipation of increases in the demand for aluminum. U.S. Steel had followed the opposite strategy of limiting output in order to maintain price above the competitive level. It would seem that a monopolist should be encouraged to expand rather than to restrict its output; to reduce prices to meet competition, unless the price reduction is below long-run marginal cost and made with intent to exclude; and to trade high prices and monopoly profits for continued possession of a large market share.

\section{Boycotts}

The antitrust boycott cases involve a heterogeneous body of practices, many of which are not exclusionary, at least in any sense relevant to an economically rational antitrust policy. The Kiefer-Stewart case ${ }^{63}$ involved a nonexclusionary boycott. Two producers had stopped selling to a wholesaler who refused to comply with their resale price ceilings. The only victim of the producers' refusal to deal was a customer; there was no exclusion of actual or potential competitors. The Court found an illegal boycott, implying that every price-fixing case is also a boycott case, since naturally the members of a cartel will refuse to sell to a customer who is unwilling to pay the cartel price.

A second irrelevant body of boycott cases is illustrated by Silver $v$. New York Stock Exchange, ${ }^{64}$ in which the Supreme Court held that it was a violation of the Sherman Act for the stock exchange to exclude a

60 The level of economic analysis in the United Shoe Machinery opinion is low. But the fault does not lie with the district court; it lies with the court's economist law clerk. See C. Kaysen, United States v. United Shoe Machinery Corporation: An Economic ANALYSIS OF AN ANTI-TRUST CASE 64-72 (1956).

61 United States v. United States Steel Corp., 251 U.S. 417 (1920); see text at note 2 supra.

62 United States v. Aluminum Co. of America, 148 F.2d 416 (2d Cir. 1945).

63 Kiefer-Stewart Co. v. Joseph E. Seagram \& Sons, Inc., 340 U.S. 211 (1951).

64373 U.S. 341 (1963). 
broker from access to its facilities without giving him a hearing. The Court seemed to consider the reason for exclusion irrelevant; it did not require proof that the broker was excluded in order to limit competition (perhaps because he was a price cutter) or that his exclusion was likely to have any anticompetitive effects. It is interesting to note that the stock exchange is a cartel $;^{65}$ Silver and other cases ${ }^{66}$ can be read as supporting the curious proposition that members of a cartel have a legal duty-imposed by antitrust law-to deal fairly with each other.

The boycotts that are an appropriate subject of attention under the antitrust laws are of two types, illustrated by the Eastern States ${ }^{67}$ and Fashion Originators ${ }^{38}$ cases. Eastern States involved a blacklist by retail lumber dealers of any wholesalers who sold directly to a retail purchaser, that is, to a customer of one of the dealers. The success of the blacklist did not depend on enlisting the customers' cooperation, and this fact distinguishes the case from exclusive dealing. Success depended on two things: first, that the retail dealers possessed monopsony power vis-à-vis any single wholesaler (otherwise the threat of cutting him off would not induce him to forego profitable sales to retail customers); second, that the wholesalers were not sufficiently well organized to make a credible threat to cut off a boycotting retailer from alternative sources of supply.

By refusing to deal, the retailers lost the profits they could have obtained from charging the wholesalers for the privilege of selling directly to consumers. Stated otherwise, the monopsony price might have been lower without the blacklist, since the blacklist imposed an extra cost on the wholesalers in the form of lost profits of direct selling. The refusal to deal may, however, have made better sense than depressing the purchase price if either one of two conditions existed: (1) the wholesalers' direct sales to consumers hurt the retailers more than they helped the wholesalers; ${ }^{69}$ (2) the retail dealers found it easier (cheaper) to agree to cut off direct-selling wholesalers than to agree on the optimum monopsony price.

In Fashion Originators', a guild of dress manufacturers threatened to stop selling to any retailer who carried the dresses of competing manufacturers, which the guild called "style pirates." In effect, the guild was trying to force the retailer to buy exclusively from its members. Our

65 See Baxter, NYSE Fixed Commission Rates: A Private Gartel Goes Public, 22 STAN. L. REv. 675 (1970).

66 E.g., United States v. Terminal R.R. Ass'n, 224 U.S. 383 (1912); see note 21 supra.

67 Eastern States Retail Lumber Dealers' Ass'n v. United States, 234 U.S. 600 (1914).

88 Fashion Originators' Guild of America v. FTC, 312 U.S. 457 (1941).

$6 \theta$ This effect might exist because the wholesalers were less efficient at direct selling than the retailers and were able to do so profitably only because the retailers were charging monopoly prices. 
earlier discussion indicates that the guild may have had to pay a high price to prevent the "style pirates" from opening retail outlets. But if efficient distribution requires that a variety of clothing styles be made available in each retail store, which is probably true, the costs of opening retail outlets may have been prohibitive for the "style pirates." As further support for the conjecture that this case was that rare instance in which exclusive dealing is an effective exclusionary tactic, no party suggested any nonexclusionary purpose for the boycott. The court did consider whether the exclusion was justified because the style pirates were guilty of a tort, but this contention was rejected on the facts. The Court also said, however, that the attempted justification was irrelevant. The justification is actually decisive, since it is not a proper purpose of the antitrust laws to protect unfair competition. ${ }^{70}$

The conclusion is that where a boycott is designed to exclude competition, it should be prima facie unlawful. Eastern States and Fashion Originators' were correctly decided, because the only purpose of the challenged practices was to exclude competition and no justification compatible with the aims of antitrust policy was established.

\section{The Exclusionary Pragtices as Torts}

To try to exclude a competitor is not always irrational; even if it were, one might still want to punish the attempt. The most difficult question raised by the exclusionary practices is not whether such practices exist, which is the focus of the debate between the Chicago School and its opponents, but whether they are sufficiently dangerous to justify extremely costly enforcement efforts, costly because of the difficulty of distinguishing between exclusionary practices and practices that promote efficiency.

I am far from being confident that the practices are sufficiently dangerous to justify attempting to prohibit them, but even if they are, they are not necessarily a fit subject for public enforcement. The case for public enforcement is strongest either where the victims of a socially undesirable practice have no incentive to bring a private action, perhaps because the cost of the violation to any victim is small, or where effective deterrence can only be accomplished by imprisonment or some other form of punishment not involving a transfer payment to the vic-

70 Donald Turner has pointed out that allowing the use of boycotts to enforce tort law or other sources of legal rights might be objectionable as interfering with a more or less carefully calibrated or proportioned system of legal remedies. This observation may be accurate but it is not an objection founded on the policy of the antitrust laws, which is to prevent monopoly. 
tim. ${ }^{71}$ The second reason is actually part of the first: without the transfer payment the victim would have no incentive to sue. These factors do not apply to the exclusionary practices. The costs to the victim, invariably a business firm and not an individual, of being excluded from a market by an exclusionary practice are substantial, and the wrongdoer can almost always be deterred by an appropriately heavy monetary penalty.

Private enforcement of federal antitrust law against the exclusionary practices suffers, however, from the serious drawback, discussed above, that Congress and the Supreme Court appear to be unable to formulate reasonable antitrust rules at tolerable cost. Perhaps a public monopoly of enforcement in this area is the best idea after all. An alternative would be to remit the victims of exclusionary practices to their remedies under state tort law. ${ }^{\mathbf{2}}$

Whatever the legal basis on which exclusionary practices are challenged, it seems clear that actual damages should be the measure of a successful plaintiff's recovery (except possibly in predatory-pricing cases), and that punitive damages should not be allowed. The only justification for the treble-damage remedy of federal antitrust law is that antitrust violations are concealable, so that actual damages often fail to place the full costs of a violation on the violator. If a potential violator evaluated the costs of a concealable violation, he would discount the applicable penalty by the less-than-certain probability of getting caught. In such a case, actual damages are an inadequate deterrent. The exclusionary practices, however, are generally not concealable-a partial exception is predatory pricing ${ }^{73}$ - and the award of treble damages thus creates an excessive inducement to sue.

$71 \mathrm{~A}$ more systematic and comprehensive analysis of the choice between public and private enforcement, but one that does not affect the present discussion, may be found in W. Landes \& R. Posner, The Private Enforcement of Law, May 1974 (unpublished paper).

72 State legislatures and courts do not appear to be overburdened to the same degree as their federal counterparts; conceivably the state courts would develop a body of tort doctrine applicable to the exclusionary practices that was in accord with proper economic considerations. Cf. Posner, A Theory of Negligence, 1 J. Legal Studies 29 (1972). This suggestion is highly speculative. Its feasibility depends on such questions as whether state laws would develop with sufficient uniformity and whether state courts would be able to handle the additional work load.

73 Predatory pricing is a possible exception because of the injured competitor's lack of information about the alleged predator's costs, which makes it difficult to distinguish between predatory and efficient pricing. However, if a firm observes that a competitor is selling below its costs, the firm is on notice that the competitor may be selling below his own costs. Whether he actually is can be ascertained through discovery proceedings. Double damages might make better sense than treble damages, in recognition of the fact that predatory pricing is less concealable than price fixing. 